Vol.4 No.2

\title{
IMPACT MICROFINANCE CREDIT ACCESS TO IMPROVE HOUSEHOLD WELFARE : EVIDENCE LONGITUDINAL DATA
}

\section{Gigih Prihantono}

Department of Economics, Universitas Airlangga

A R T I C LE INFO

Keywords : $\quad$ microfinance
access, household

Kata Kunci : akses keuangan mikro, rumah tangga

Abstrak : Bukti pada layanan keuangan mikro hari ini Ironisnya menunjukkan preferensi besar untuk produk tabungan daripada produk-produk kredit oleh rumah tangga. Untuk beberapa penulis, fenomena ini dijelaskan oleh fakta bahwa produk-produk keuangan mikro, dan terutama pinjaman, dari lembaga-lembaga keuangan mikro formal tidak sesuai kebutuhan rumah tangga. Makalah ini pertama menyajikan bukti tentang fenomena diamati di sektor keuangan mikro di Indonesia. Kedua, ini menganalisa pasar kredit Indonesia untuk memahami faktor-faktor penentu pilihan untuk kredit dari sumber-sumber resmi versus sumber informal. Hasil mengungkapkan ukuran pinjaman, keperluan pertanian, wilayah geografis di mana rumah tangga tinggal dan etnis sebagai faktor-faktor yang mempengaruhi pilihan untuk sumber-sumber resmi. 


\section{Background}

\section{INTRODUCTION}

Microfinance has come to be regarded as an important vehicle to reduce the incidence of rural poverty. An increasing proportion of the rural poor in many developing countries receive credit from microfinance institutions (MFIs). It is estimated that microfinance now serves more than 150 million borrowers (Hartarska et al., 2013). As noted by Servin et al. (2012, p. 2136): "Some observers [have] even called the development of microfinance. . . one of the main innovations in the past 25 years"'. No doubt, such claims reflect the increasing public recognition that microfinance has received over the last decade, stemming from the United Nations decision to declare 2005 as the Year of Microfinance and that Mohammad Yunus and the Grameen Bank were awarded the Nobel Peace Prize in 2006. The extremely rosy view of microfi-nance as a means to tackle rural poverty, however, has started to be questioned in recent studies of microfinance (Servin et al., 2012).

To this point existing studies of microfinance have focused pri-marily on the effect of microfinance on assets, consumption, income and profits (Banerjee et al., 2013; Crépon et al., 2014; Kaboski and Townsend, 2005, 2012; Khandker, 2005; Lensink and Pham, 2012; Morduch, 1998; Pitt and Khandker, 1998, 2002) as well as the role of microfinance in mitigating the effects of health and income shocks (Gertler et al., 2009; Islam and Maitra, 2012). Other studies have focused on the effect of relationships between borrower and lender on access to finance and loan conditions in microlending (Behr et al., 2011) or on corporate governance and the relationship between economies of scale, ownership and effi-ciency in MFIs (Galema et al., 2012; Hartarska, 2005; Hartarska and Mersland, 2012; Hartarska et al., 2013; Hermes et al., 2011). However, these studies do not consider how successful microfinance has been in terms of reducing the reliance of poor households on informal loans.1 One of the key objectives of microfinance is to reduce the reliance of the poor on informal moneylenders. This objective, for example, is clearly enunciated in Grameen Bank documents (see eg. Yunus, 1994) and is accepted in the extant literature on microfinance (Jain and Mansuri, 2003). The extent to which microfinance has been successful in reducing the reliance of the poor on informal lenders is important given that informal moneylenders typically charge exorbitant interest rates on loans and eat into the savings of borrowers (Mallick, 2012). By contrast, microfinance programs are targeted at the poor and are designed to actively promote savings.

Evidence from the existing empirical literature on the effect of access to microfinance on informal lending among the poor, and near poor, is mixed. As noted by Besley et al. (2012), and also emphasised by Mookherjee and Motta (2013), the presence of the MFI can provide an outside option for poor borrowers that effectively reduces the level of 'exploitation' by informal lenders. Khandker (2000) finds that being a member of an MFI reduces the incidence of borrowing from an informal source. He also finds heterogeneous effects: male members reduce household borrow-ing from informal sources, but this is not the case for female mem-bers. On the other hand, Sinha and Matin (1998) find that microfinance member households do not reduce borrowing from informal credit sources. Menkhoff and Rungruxsirivorn (2011) analyse the role of village funds in rural Thailand. Their findings suggest that loans from informal sources are more likely to be used for shock absorption than loans from village funds. They do not find any evidence that village funds act as a substitute for informal lenders. Similar studies, in the context of village funds in Thailand, also find that borrowers from village funds do not reduce their level of informal borrowing (Kaboski and Townsend, 2012; Kislat and Menkhoff, 2011). Karlan and Zinman (2010) show a positive impact of mar-ginal loans on households having a credit score, but no impact on the score itself over a 15 to 27 month period. This seems con-trary to the existence of a vicious circle of debt. However, given the existence of asymmetric information, the credit score that is assessed by the lender might not fully reflect the borrower's debt situation, due to debt underreporting and exclusion of informal borrowings from friends and/or family.

The purpose of this paper is to examine whether access to microfinance reduces the reliance of the poor, and near poor, on informal lending among households in Indonesia. To do so, we use a unique panel data set, collected over three rounds spanning more than two decades (1994-2008). The availability of detailed borrowing data at the household level in 1994 enables us to compare the outcome before and after microfinance was available to these households. The long time span allows us to examine the effect of microfinance on informal lending in the very long run and over a much longer time period than previous studies. We also examine heterogeneous effects of microfinance across occupations and poverty status. We take advantage of having data at the individual level to identify heterogeneity in access to micro-finance between male and female household members. The avail-ability of 
household level panel data allows us to address the concerns of potential selection bias regarding the decision to be a member of an MFI and placement of an MFI at the village level.

\section{THEORETICAL FRAMEWORK}

\section{Effect of Microfinance on Borrowing}

The theoretical predictions of the effect of microfinance on the informal credit market remain ambiguous. As a rationale for MFIs to intervene in rural credit markets, it has been argued that MFIs can efficiently substitute for informal lenders who are commonly viewed as being exploitative (Armendáriz and Morduch, 2010). Due to lack of collateral, the poor in developing countries are mostly unable to access credit from the formal financial sector. Instead, they borrow from informal lenders, who typically charge excessively high interest rates. Given the crucial role of access to affordable credit in promoting households' productive activities, credit rationing is a major obstacle preventing households in developing countries from escaping the poverty trap (Paulson and Townsend, 2004). The high interest rates charged by informal lenders have been explained by the existence of high default rates (Collins et al., 2009) and absence of returns to scale (Aleem, 1990). MFIs can be regarded as an efficient substitute for informal lenders given their innovative group lending approach and high returns to scale due to their large coverage of clients, which ensures the pro-vision of more favourable interest rates (Armendáriz and Morduch, 2010; Meyer, 2002; Robinson, 2001). Due to this improved access to affordable credit, the poor may be expected to borrow more from MFIs and reduce their reliance on the provision of informal credit (Khandker, 2000).

On the other hand, there is widespread anecdotal evidence that households borrow concurrently from both MFIs and informal sources (Jain and Mansuri, 2003; Sinha and Matin, 1998). One possible reason for the coexistence of microfinance and informal lending is that microfinance members may need to borrow in the informal market in order to repay microfinance loans (Sinha and Matin, 1998). Alternatively, microfinance loans with a strict repay-ment schedule might be less favourable than informal loans which allow for much more flexibility (Collins et al., 2009). The coexis-tence of microfinance and informal lending has also been explained in a number of theoretical papers. Jain and Mansuri (2003) argue that an instalment repayment plan with a strict sche-dule allows MFIs to exploit the better monitoring capability of the informal lenders in constraining strategic behaviour by borrowers. Therefore, the entry of an MFI into a village might stimulate the activities of the informal lenders. Other theoretical studies also attribute the prevalence of an informal credit market to its infor-mational advantage over formal institutions (Hoff and Stiglitz, 1990; Stiglitz and Weiss, 1981). Other reasons include high trans-action costs involved during the loan application process to formal or microfinance institutions, making the cost of borrowing from the informal sector relatively cheaper (Barham et al., 1996; Guirkinger, 2008; Mushinski, 1999) and the lower risk involved in entering into a borrowing contract with informal lenders (Boucher and Guirkinger, 2007; Guirkinger, 2008). An alternative explanation for an increase in informal borrowing is provided in McIntosh and Wydick (2005), who show that MFI competition can increase asymmetric information among lenders, thus creating an incentive for the most impatient borrowers to take multiple loans and increase their debt levels. Thus, we have the following competing hypotheses:

H1. Provision of microfinance reduces household reliance on informal borrowing.

H1a. Provision of microfinance increases household reliance on informal borrowing

\section{Heterogeneous Effects of Microfinance Borrowing}

We expect heterogeneous effects of microfinance provision on informal borrowing depending on the poverty level of the house-hold and the household's propensity to engage in business. In terms of poverty level, we distinguish between poorer, and less poor, households. Households who are less poor are better placed to replace informal borrowing with microfinance because they have the resources to meet 
microfinance repayment schedules without having to resort to informal borrowing. By contrast, households that are poorer are likely to be more impatient and less endowed with collateral and, as such, more exposed to the strict microfinance repayment schedule. Mookherjee and Motta (2013) present a model in which MFIs attract both safe households with more land holdings and risky households with less land. They show that poorer microfinance borrowers tend to be risk-taking and bor-row more from informal sources to meet microfinance repayments. Data in Jain and Mansuri (2003) and Sinha and Matin (1998) also suggest that poorer households borrow more from informal sources in order to service debt repayment, compared with less poor households.

Microfinance creates an increased demand for credit from informal sources as business expands and microfinance alone cannot meet the borrower's credit needs (Khandker, 2000; Mallick, 2012). Crépon et al. (2014) find that access to microfi-nance assisted households to expand their self-employment activities, as seen by a significant increase in investment in assets used for animal husbandry and agriculture. Similarly, Mallick (2012) finds that moneylenders' interest rates increase in response to the provision of microfinance, particularly in villages in which loans are more likely to be invested in productive activities, rather than used for consumption purposes. If the demand for credit increases with new business opportunities, we should find that households who have higher propensity to start a new busi-ness following access to microfinance borrow more from informal sources.

Since we are interested in understanding the welfare effect of microfinance on a household's informal borrowing, it is also important to disentangle the demand and supply effects. Our analysis of heterogeneity can help us identify the demand effect; namely, whether the demand for credit increases and, if so, whether the increase reflects loan repayments or new business investment. In order to examine the supply effect, we would need to analyse how informal lenders respond to the presence of MFIs. In Mookherjee and Motta's (2013) model informal credit mar-kets are characterized by adverse selection and segmentation. In their model, MFIs have an informational disadvantage vis-à-vis informal lenders, but have access to capital at lower cost. MFIs and informal lenders co-exist with MFIs, attracting certain catego-ries of borrowers (high risk borrowers and safe borrowers with enough land to shoulder the burden of joint liability). On the basis of the above discussion, we propose, and test, the following hypotheses: concerning heterogenous effects:

$\mathrm{H} 2$. Provision of microfinance increases informal borrowing for households with high propensity to start a new business.

H3. Provision of microfinance reduces informal borrowing for less poor households, but increases it for poorer households.

\section{Effect of Microfinance on Borrowing by Females}

While most microfinance members are female, their microfi-nance loans are most likely to fall under the control of their hus-bands (Goetz and Gupta, 1996; Rahman, 1999). The decision to borrow from informal sources, and the purpose for which the loan is employed, also tends to be made by the husbands. In the dataset employed in this study, in the baseline only 3 percent of borrowers from informal sources were women. Sinha and Matin (1998) suggests that women without microfinance access could not borrow from informal sources, since they are not seen as a good credit risk and are not in the habit of borrowing. Females are disadvantaged vis-à-vis males in terms of collateral requirements and credit availability (Bellucci et al., 2010) on the relevance of collateral in emerging markets see Menkhoff et al. (2012). If microfinance loans are under the control of men, and if microfinance access does not have any empower-ment effects on women, we would not expect to see an effect on informal borrowing by women.

However, becoming an MFI member may increase both a women's need, and ability, to borrow from informal sources. While it is possible that women cede control of their informal loans to their husbands, any increase in women's informal borrowing suggests a reduction in their credit constraint as well as an increase in their involvement in the household's financial decision making. In interviews with 
Grameen Bank borrowers reported in Sinha and Matin (1998), female borrowers reported that they could bor-row more from moneylenders due to their almost assured credit from Grameen, that money-lenders would keep track of their Grameen loan disbursements and "even follow the borrower to the Bank on the day of the disbursement". Alternatively, women with microfinance membership might have to take responsibility for repaying microfinance loans and thus need to borrow more for repayment purposes. Grameen Bank female borrowers were not in the habit of borrowing before joining MFIs, but the need to borrow from informal sources became more common when they started borrowing from MFIs and when their microfinance loan amounts increased (Sinha and Matin, 1998). On the basis of the above discussion, we test the following hypothesis:

H4. Provision of microfinance increases women's informal borrowing.

\section{Data}

\section{RESEARCH METHOD}

Our data set is nationally representative panel data Indonesia Family Life Survey (IFLS), which was collected by the Rand Corporation in three waves in 1994, 2000, and 2008. The baseline survey was administered in 1994-2008 to 10.500 rural households from 72 villages in 57 out of 13 Province in Indonesia. IFLS researchers used a stratified random sampling method. First, 72 unions were randomly selected from all unions in Indonesia; then one village was selected from each union that best represented the union in terms of the size of land holding and literacy rate. All the households in the selected villages were stratified by the size of land ownership and land ten-ure, then a random sample of 20 households was drawn from each village such that the structure of landownership and land tenure of all households was represented. Microfinance Institution (MFI) barely existed in these villages in Indonesia at the time of the baseline survey in 1994. Hence, an important and distin-guishing feature of this dataset is that we have information on households that were not a member of an MFI at the time of the baseline survey, but subsequently became a member of an MFI when microfinance became available in their community. In most villages, no villager reported being a member of an MFI in 1994. We drop two villages (from two districts) from the dataset as more than five (six and eight) villagers in these villages reported being MFI members. This is to ensure that we have a clean baseline data set that does not include any village in which MFIs might be present. For 15 other villages in which less than five (mostly one to two) villagers reported being MFI members, we keep the villages but drop those MFI members. We keep these villages in the sample because there were no MFIs in these villages at the time. It is likely that a few households did not understand the difference between a microfinance loan and other similar loans (e.g., cooperative society loans) that existed at that time. The pre-program dataset also con-tains extensive information about participation of both the house-hold and each individual member within a household in formal and informal borrowing.

\section{Model PSM}

We need to address a number of concerns regarding the decision to be a member of an MFI and placement of an MFI at the village level. For example, it could be the case that villages with more informal lenders get priority for microfinance as that would encourage many people to participate considering the demand for loans. That is, the decision to locate an MFI might come about because of strong demand from a local community. Moreover, households within the program villages self-select into the pro-gram. Participating households are also different in terms of a number of observable characteristics as shown in the previous sec-tion. The decision to participate in a program could be driven by the perceived benefit from such credit (for example, availability of lower interest rates compared to what local money lenders offer). Below we address this concern based on selection on observables. We also address the potential concern that the deci-sion to participate in a microfinance program is likely to be based on unobserved characteristics.

First, we consider balancing the observed characteristics between participating and non-participating households. In order to do so we use the PSM method and select samples based on their propensity to participate in the microfinance program. PSM can directly compare the outcomes for participant and non-participant households with the same (or similar) values of those variables thought to influence both participation in microfinance and outcomes in the absence of the program. We therefore match households based on their socio-economic status. We include a number of pre-program level household characteristics and restrict our analysis to the matched sample. This 86 
approach controls for heterogeneity in initial socioeconomic conditions that may be correlated with the subsequent decision to participate in microfi-nance.

However, it is likely that there are unobservables at both house-hold and village level and that these determine participation in the program or placement of a program in a village. As a result, partic-ipation in the microfinance program may not be orthogonal to unobservable factors that also affect the outcome of interest. Thus to control for the unobserved characteristics that influence households' decision to participate in a microcredit program and borrowing from informal sources, we employ a household fixed-effect regression in estimating the effect of microfinance on informal loans as follows:

\section{【Loan》_it $=\alpha+\beta \_1$ Treat》_it $+\beta \_2 Y \_i t+\mu \_i+\sigma \_t+\lambda \_i t+\gamma \_t$}

Where loanit is the informal loan borrowed by a household with identification number $\mathrm{i}$ in the current round $(\mathrm{t})$ and identification number $\mathrm{j}$ in the first round (identification differs between the first and subsequent rounds for split households), who live in village $\mathrm{v}$ in survey round $\mathrm{t}$. We use both incidence and amount of borrowing from informal sources. For the incidence of borrowing, loan $=1$ if a household bor-rowed money from informal sources. It is equal to the total amount (in taka) borrowed from informal sources when we examine the amount of loans. For the latter, we use the full sample, including those who did not borrow any money from informal sources. There are only $13 \%$ of original households who borrowed in the second round from informal sources. 'Treat' is the treatment status variable, which is equal to 1 if, in the second round, if the household had any microfinance loan from an MFI during the previous year and zero otherwise. We also use alternative treatment variables, includ-ing the number of years of membership in a microfinance program. Although we do not have data on the total accumulative amount of microfinance borrowing, the membership duration variable can be used as a proxy. The vector X includes household characteristics that affect households' demand for loans: household head's age, gender and education, household size, number of unwell members, total value of household agricultural assets, total owned cultivable land, maximum education level of female members and number of female members.

The time dummy equals 1 if the observations come from the second round. $\mathrm{kv} t$ is the village trend, which captures any village time-varying factors. The time dummies control for prices, such as interest rates, and the interaction of the time dummies with the village fixed effects allows us to control for price changes that are vil-lagespecific over time. They also enable us to control for village level shocks that might affect informal borrowing across villages dif-ferently or the decision of an MFI to locate to a particular village. $\mathrm{lj}$ and $\mathrm{rv}$ are household and village fixed effects. The village fixed effects are in effect accounted for when we control for household fixed effects in our regressions.

\section{Attrition and Split Household}

We first examine whether there is any attrition bias. There are 353 households who were surveyed in the first round, but not in the second round, representing 12 percent of the original sample. Another 127 households dropped out from the survey after the second round. The attrition rate is very low considering the two-decade-long period of the survey. Following Fitzgerald et al. (1998), we test for attrition bias that is due to observables. We esti-mate a probit model of attrition using lagged demographic vari-ables and outcome variables to explain the attrition probability in the subsequent round and find no significant correlation between attrition probability and the lagged variables. To account for selection on unobservables, we also run a weighted least squares (WLS) regression. In particular, we use the inverse of the probability of remaining in the sample between rounds, computed from the probit, for attrition. The weight assigned to estimation is described in detail in the next sec-tion. We find that the results are similar with, or without, weight-ing4. It is to be noted that a number of studies on attrition bias suggest that attrition is mostly random and even if it is not, the effect of attrition on outcome estimates are insignificant (Alderman et al., 2001; Falaris, 2003; Fitzgerald et al., 1998; Thomas et al., 2001).

Due to the long time period between the baseline round and the second round, the percentage of newly formed households is large. About 40 percent of original households in the baseline survey had split into more than one household by the second survey round. The percentage of split households in the third round, compared with the second round, is relatively small; only 8 percent of the households surveyed in 2000 had split by 2007-2008. We consider split households as separate households, due to their considerable number and the nature of borrowing in the second round. Thus, each split household is treated as an independent unit for the purpose of constructing outcome and control variables, but we use the baseline household identification when using household fixed effects. 
We also run a robustness check, in which we exclude all split households and the main results are similar to what we find when these split households are included. We discuss this further below.

\section{Heterogeneous Effects}

Given that MFIs prioritize supporting household businesses, it is possible that access to microfinance could create new business opportunities, or expand existing ones, thus affecting household demand for credit besides offering them an additional source of credit. While microfinance loans are ostensibly restricted to busi-ness purposes, the restriction is not always imposed strictly with monitoring. Therefore, the use of loans remains at the discretion of the borrowers. MFI members are observed to use microfinance loans for various purposes outside business. Our data shows that in the second round, only 27 percent of all treatment households have a business, so the majority of households having access to microfinance seem to use their microfinance loans for purposes other than business. Therefore, we expect heterogeneous effects of microfinance access among member households, possibly differ-ing across their income-earning activities and poverty level. To examine this heterogeneity, we include interaction terms between treatment status and households' main earning activities. Based on the primary occupation of household heads at the baseline, we cat-egorized these activities into business, home agriculture, and wage labour (including services and paid labour). Moreover, motivated by the evidence on differences between target households and nontarget households in terms of their use of microfinance loans, we also interact the treatment variable with the household's pov-erty level: the poor or the less poor. We categorize the poor and the less poor based on MFIs' target criteria on household's owned land. Specifically, we use household's total owned cultivable land at the baseline. A household is defined as poor if it owns less than 0.5 acres of cultivable land area.

\section{Medium and Long-Run Effects}

In order to estimate the long-run effects, we look at how infor-mal borrowing changed between the baseline (1993/94) and the final survey round (2008) for households who were microfinance members since 2000. We then compare with changes in informal borrowing of these households between the baseline and 2000 sur-vey round. Thus, we estimate Eq. (1) using data from the first and third rounds, but define the treatment variable as household's par-ticipation status in the second round instead of in the third round (we call this the 'long-run effect'). We then compare the new results with the results we get from Eq. (1) using data from the first two rounds (we call this the 'medium-run effect').

The modified equation is defined as follows:

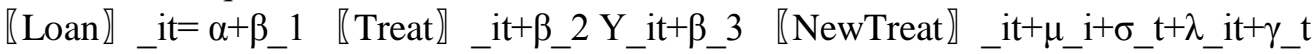

In Eq. (2), we add a variable 'NewTreat', which is equal to 1 if the household borrowed from microfinance in the third round, but not in the second round, and equal to zero otherwise. If we only use 'Treat' as household's treatment status in the second round, our estimate of the effect of microfinance on informal borrowing might be underestimated due to the inclusion of 278 households who were new microfinance borrowers in the third round. Among households who borrowed from microfinance in the second round, 101 households dropped out from microfinance in the third round. As we expect the long-run effect of microfinance to vary between those households who drop out and those who continue to borrow from microfinance by the third round, we estimate Eq. (2) again, but this time excluding the households that dropped out.

\section{Descriptive Statistics}

\section{RESULT AND DISCUSSION}

\section{Tabel 1.Descriptive Statistics For Household Characteristic}

\begin{tabular}{|c|c|c|c|c|c|c|}
\hline \multirow[t]{2}{*}{ No. of observations } & \multicolumn{2}{|c|}{$\begin{array}{l}\text { Round } 1 \\
1010\end{array}$} & \multicolumn{2}{|c|}{$\begin{array}{l}\text { Round } 2 \text { difference (MF borrower-non borrower) } \\
1360\end{array}$} & \multicolumn{2}{|c|}{$\begin{array}{l}\text { Round } 3 \text { difference (MF borrower-non borrower) } \\
1368\end{array}$} \\
\hline & Mean & Std & Mean & Std & Mean & Std \\
\hline Head age & 41.74 & 14.14 & $-3.09^{* * *}$ & 0.94 & $-3.72^{* * *}$ & 0.82 \\
\hline Female head & 0.06 & 0.24 & $-0.04^{* *}$ & 0.02 & $-0.11^{* * *}$ & 0.02 \\
\hline Head education & 3.13 & 3.93 & $-1.08^{* * *}$ & 0.30 & $-0.80^{* * *}$ & 0.25 \\
\hline Household size & 5.95 & 2.79 & -0.19 & 0.17 & 0.10 & 0.13 \\
\hline No of disabled/unwell members & 0.20 & 0.48 & -0.10 & 0.07 & $-0.10^{* * *}$ & 0.04 \\
\hline No of children & 2.26 & 1.60 & 0.04 & 0.09 & -0.01 & 0.07 \\
\hline Cultivable land (ha) & 0.38 & 0.87 & $-0.14^{* * *}$ & 0.04 & $-0.10^{* * *}$ & 0.02 \\
\hline Agricultural assets (taka) & 7,124 & 13,935 & $-1,684^{* *}$ & 707 & $-1,133$ & 894 \\
\hline Max female education & 2.45 & 3.16 & $-0.62^{* *}$ & 0.26 & -0.17 & 0.22 \\
\hline No of female members & 2.91 & 1.63 & -0.11 & 0.10 & 0.01 & 0.08 \\
\hline
\end{tabular}


. In Table 1, we report descriptive statistics at the baseline and the mean difference between microfinance member and non-member households in the second and third rounds for households' demographic charac-teristics. The number of observations across survey rounds differs due to splitting households. There are some significant differences between member and non-member groups. Major differences are household head's education, land and non-land assets, and house-holds' main earning activities. Treatment households have less land and non-land assets than control households in all three rounds. Therefore, treatment households are also less likely to work on home agriculture. Household heads in the treatment households also have lower education than their counterparts in the control households.

The difference between participating households and non-par-ticipating households in a number of observable characteristics reflected above raises a potential concern regarding selection bias into the program. Both the household's decision to participate in microcredit and its borrowing from informal sources could be dri-ven by differences between observed and unobserved characteris-tics between participants and non-participants. We control for these variables in our regression modelling. We also use methods that can account for unobservables that are time invariant. In addi-tion, we use the PSM method, which was initially proposed by Rosenbaum and Rubin (1983). With PSM, participants are com-pared with matched non-participants (based on propensity scores), while controlling for the characteristics that are potential determi-nants of participation in microfinance.

\section{Average Effect of Microfinance on Informal Borrowing}

Table 2 reports the estimation results from Eq. (1), examining the effect of microfinance access, measured alternatively by a dummy variable for microfinance borrowing in the previous year or the number of years for which a household has been a member, on the household's borrowing from informal sources. Column (1) of Table 2A shows that having loans from MFIs reduces the incidence of informal borrowing during that year. An increase in the number of years for which a household is a member of MFIs also reduces the propensity to borrow from informal sources (column (1), Table 2B). However, in column (3) we find no significant effect of microfinance access on households' total amount of informal loans. While households with microfinance access are less likely to bor-row from informal sources, those that continue to borrow do not borrow less than their non-member counterparts. Thus, we find partial support for $\mathrm{H} 1$, at least with respect to the incidence of informal loans.

The findings possibly reflect the fact that before having microfinance access, households could not afford to invest in new productive activities including opening new home businesses or adopting new farming technologies. Thus, their only demand was for consumption borrowing alone. That microfinance loans provide MFI members with opportunities to invest in these activi-ties means that microfinance members may need to supplement microfinance borrowing with informal loans for productive activi-ties. In addition, having microfinance loans could also increase household's need for extra funds for loan repayments, given the tight repayment schedule by MFIs and that new productive activ-ities require time for profit realization. This also suggests that het-erogeneous effects of microfinance access among member households differ across their baseline income-earning activities and poverty level. Depending on their conditions before borrowing from microfinance, access to microfinance might also change households' credit demand in addition to changing their supply of credit. We explore these possibilities below. 


\begin{tabular}{|c|c|c|c|c|}
\hline Variables & (1) & (2) & (3) & (4) \\
\hline & Loan incidence & & Loan amount & \\
\hline $\begin{array}{l}\text { (A) Effect of microfinance borrowing } \\
\text { Microfinance borrower }\end{array}$ & $\begin{array}{l}-0.074 \cdots \\
(0.018)\end{array}$ & & $\begin{array}{l}-155.7 \\
(587.8)\end{array}$ & \\
\hline Microfinance borrower"business & & $(0.046)$ & & $\begin{array}{l}-1734.3 * \\
(966.1\end{array}$ \\
\hline Microfinance borrower*agriculture & & $-0.070^{\cdots+\cdots}$ & & $-809.7^{*+}$ \\
\hline Microfinance borrower*wage labour & & $\begin{array}{l}(0.023) \\
-0.045\end{array}$ & & 1429.4 \\
\hline Observations & 3705 & $(0.030)$ & & ${ }_{3760.1)}^{(1160)}$ \\
\hline Adjusted R-squared & 0.221 & 0.222 & 0.060 & 0.062 \\
\hline $\begin{array}{l}\text { (B) Effect of membership years } \\
\text { Membership years }\end{array}$ & $\begin{array}{l}-0.0086^{* * *} \\
(0.0029)\end{array}$ & & $\begin{array}{l}52.4 \\
(82.7)\end{array}$ & \\
\hline Membership years"business & & $-0.021 \cdots$ & & -38.0 \\
\hline Membership years"agriculture & & $\stackrel{(0.0054)}{-0.010^{*}}$ & & $\begin{array}{l}(128.4) \\
-127.4\end{array}$ \\
\hline Membership years"wage labour & & $\begin{array}{l}(0.0041) \\
-0.0010\end{array}$ & & $\begin{array}{l}(96.0) \\
276.5^{*}\end{array}$ \\
\hline & & $(0.0048)$ & & (161.5) \\
\hline $\begin{array}{l}\text { Observations } \\
\text { Adjusted R-squared }\end{array}$ & $\begin{array}{l}3705 \\
0.219\end{array}$ & $\begin{array}{l}3703 \\
0.220\end{array}$ & $\begin{array}{l}3705 \\
0.060\end{array}$ & $\begin{array}{l}3703 \\
0.062\end{array}$ \\
\hline
\end{tabular}

\section{Heterogenous Effects of Microfinance on Informal Borrowing by Occupation}

To examine whether the effect of microfinance access is heter-ogeneous across member households in terms of their occupation, we report results that include controls for households' main occupation at the baseline and an interaction term between these controls and microfinance access (columns (2) \& (4), Table 2). Column (2) shows that having microfinance access can reduce the propensity to borrow from informal sources for households engaged in business or agriculture, but not for those who worked as wage labour. In particular, having microfinance access reduced the pro-pensity by 16 percentage-points for households engaged in business and by 7 percentage-points for those engaged in agriculture. An additional year of membership of an MFI also reduced the propensity by 2.1 percentagepoints for households engaged in business and 1 percentage-point for households engaged in agriculture.

We find similar effects for the informal loan amount (column (4), Table 3). While we did not find any effect of microfinance access on the amount of the informal loan when looking at all households, we find microfinance has a negative effect on the informal loan amount for households engaged in business or agri-culture. Borrowing from microfinance reduced informal borrowing by about Rp.1.700.000 (\$US 130.2) for business households and Rp. 810.000 (\$US 62.3) for agricultural households. Meanwhile, the effect is in the opposite direction for households working in wage labour jobs. While the effect of microfinance access is positive, but not sig-nificant, the longer the households borrowed from microfinance, the more they have to borrow from informal sources (column (4), Table 3B). In particular, households with wage labour jobs increased their informal borrowing by Rp. 277.000 (\$US 21.3) with each additional year of microfinance membership.

The notable heterogeneity among households with different occupations suggests that microfinance not only increased house-holds' supply of funds, but also changed households' demand for credit and/or their access to informal loans. If access to microfi-nance only affected the supply of funds, we expect all microfinance borrowers to either reduce, or not change, their informal borrowing. However, the increase in informal loans for microfinance member households doing wage labour jobs implies that access to microfi-nance increased their demand for credit and/or improved their credit trustworthiness, so that they could borrow more from informal lend-ers. First, households with a better track record of microfinance bor-rowing (observable through longer membership duration) are more likely to have access to other lending sources, especially informal lenders, from whom they could not borrow before. Second, the increase in credit demand could reflect there being insufficient funds from microfinance and/or the strict repayment requirements by MFIs that means borrowers often do not have enough time to make profits before loan repayments are due. 
Even if microfinance borrowers used microfinance loans for consumption purposes, rather than productive investments, they also need to borrow more from informal sources to service micro-finance debt, and the deteriorating effect of cumulative debt in the long run might even be worse since they earn no profit from micro-finance loans. While microfinance aims to offer new business opportunities to households, households without a business or home agricultural production before joining MFIs are more likely to need supplementary credit than those who already have a busi-ness or production due to the high set-up cost. To test for this, we run a regression testing the relationship between a household's informal borrowing and its main occupation, controlling for house-hold fixed effects, other time-varying household characteristics and a village time trend.

Table 3. Occupational Transition of Borowers and Non Borrowers of Microfinance

\begin{tabular}{|c|c|c|c|c|c|c|c|}
\hline & & \multicolumn{6}{|l|}{2000} \\
\hline & & \multicolumn{3}{|c|}{ Non borrower } & \multicolumn{3}{|c|}{ Microfinance borrower } \\
\hline & & Business & Agriculture & Labour & Business & Agriculture & Labour \\
\hline \multirow{5}{*}{1994} & Business & 42.62 & 25.41 & 31.97 & 43.59 & 25.64 & 30.77 \\
\hline & Agriculture & 12.9 & 64.3 & 22.8 & 19.87 & 56.29 & 23.84 \\
\hline & Labour & $\begin{array}{l}16.49 \\
2008\end{array}$ & 32.26 & 51.25 & 29.27 & 26.02 & 44.72 \\
\hline & & Non borrc & & & \multicolumn{3}{|c|}{ Microfinance borrower } \\
\hline & & Business & Agriculture & Labour & Business & Agriculture & Labour \\
\hline \multirow[t]{4}{*}{2000} & Business & 31.78 & 24.3 & 43.93 & 48.31 & 24.58 & 27.12 \\
\hline & Agriculture & 6.82 & 63.52 & 29.66 & 7.85 & 68.59 & 23.56 \\
\hline & Labour & $\begin{array}{l}7.17 \\
2008\end{array}$ & 24.22 & 68.61 & 13.41 & 21.95 & 64.63 \\
\hline & & Non borr & & & \multicolumn{3}{|c|}{ Microfinance borrower } \\
\hline \multirow{4}{*}{2008} & & Business & Agriculture & Labour & Business & Agriculture & Labour \\
\hline & Business & 22.55 & 17.65 & 59.8 & 50 & 21.95 & 28.05 \\
\hline & Agriculture & 10.06 & 50.7 & 39.24 & 14.94 & 51.04 & 34.02 \\
\hline & Labour & 9.62 & 28.08 & 62.31 & 15.98 & 31.96 & 52.06 \\
\hline
\end{tabular}

To examine this result more closely, we look at the trend of occupational transition of microfinance borrowers and non-borrowers over the period between 1994 and 2008. The results are reported in Table 4. In all periods, microfinance borrowers were more likely to move into business than non-borrowers by 2000 and 2008, irrespective of their starting occupation in 1994. However, the difference is most prominent among households who did wage labour jobs in 1994. In particular, 29 percent of microfinance bor-rowers who did wage labour jobs in 1994 moved into business by 2000, while the corresponding number for non-borrowers was only 17 percent. The trend is similar for the periods 1994-2008 and 2000-2008. Thus, credit demand increased for borrowers com-pared with the nonborrowers, who were less likely to move into business and invest in new productive activities. Microfinance bor-rowers who were engaged in business in 1994 or 2000 were also more likely to remain in business by 2008 (50 percent versus 23 percent for non-borrowers between 1987-2008 and 48 percent versus 32 percent between 2000-2008) while non-borrowers were more likely to move to wage labour jobs. This may explain why access to microfinance reduced informal loans for households engaged in business, but the duration of microfinance membership did not have any significant effect. While microfinance borrowers were more likely to remain in business and need funds for invest-ment in the long run, non-borrowers were more likely to become wage labourers and reduce their credit demand for investment in productive activities.

Our findings show that households moving into business in general need to borrow more, and microfinance borrowers who were wage earners in the baseline were more likely to open their own business by the second and third rounds. These results sug-gest that the increase in informal borrowing of households doing wage jobs at the baseline is most likely due to their increase in credit demand in order to realize new business opportunities. This finding supports $\mathrm{H} 2$; namely, that the provision of microfinance increases informal borrowing for households, who, in the baseline, had a high propensity to start a new business. 


\section{Conclusion}

Focusing on the role of microfinance in reducing household's reliance on informal borrowing in the medium run and long run, this paper contributes to an under-researched area in the microfi-nance literature. We first summarize our findings with respect to the four hypotheses. We find that, in general, access to microfi-nance reduced household's propensity to borrow from informal sources, but not the amount of informal loans. Therefore, there is partial support for H1. Our findings suggest that the effect of access to microfinance on the incidence and amount of informal lending is heterogeneous across poverty levels, consistent with $\mathrm{H} 2$, and that households with a propensity to engage in business borrow more, consistent with $\mathrm{H} 3$. In terms of long run versus short-run effects, the effects identified in $\mathrm{H} 1-\mathrm{H} 3$ are accentuated over time for the less poor households when they continued borrowing from micro-finance and possibly received larger loans, consistent with $\mathrm{H} 4$.

Being less dependent on informal lenders, we might expect that less poor households who continued to borrow from microfinance in the long-run may be able to benefit from income growth through increased saving and investment, which are promoted by the reduced cost of financing. As evidenced in the literature, microfinance interest rates are significantly lower than the rates charged by informal lenders (Khandker et al., 2013; Khandker and Samad, 2014; Mallick, 2012). Our data also show that the mean informal interest rate was 72 percent as opposed to the 15 percent charged by MFIs in 2000. As a result, we might expect that households who continued to borrow from microfinance may be able to invest more efficiently in inputs, labour and technologies (Sinha and Matin, 1998; Zeller et al., 1997). According to Zeller et al. (1997), access to more affordable credit can also reduce a household's cost of insurance against adverse shocks, enabling them to invest in riskier, but also more profitable, projects. Khandker et al. (2013) find that microenterprise profit is 115 per-cent higher for households that borrowed from MFIs, compared to those that borrowed from informal lenders. However, given the scope of this paper and our data availability we cannot directly examine whether these potential benefits are indeed present. This is an area that could be fruitfully examined in future research.

\section{CONCLUSION AND RECOMMENDATION}

Focusing on the role of microfinance in reducing household's reliance on informal borrowing in the medium run and long run, this paper contributes to an under-researched area in the microfi-nance literature. We first summarize our findings with respect to the four hypotheses. We find that, in general, access to microfi-nance reduced household's propensity to borrow from informal sources, but not the amount of informal loans. Therefore, there is partial support for H1. Our findings suggest that the effect of access to microfinance on the incidence and amount of informal lending is heterogeneous across poverty levels, consistent with $\mathrm{H} 2$, and that households with a propensity to engage in business borrow more, consistent with $\mathrm{H} 3$. In terms of long run versus short-run effects, the effects identified in $\mathrm{H} 1-\mathrm{H} 3$ are accentuated over time for the less poor households when they continued borrowing from micro-finance and possibly received larger loans, consistent with $\mathrm{H} 4$.

Being less dependent on informal lenders, we might expect that less poor households who continued to borrow from microfinance in the long-run may be able to benefit from income growth through increased saving and investment, which are promoted by the reduced cost of financing. As evidenced in the literature, microfinance interest rates are significantly lower than the rates charged by informal lenders (Khandker et al., 2013; Khandker and Samad, 2014; Mallick, 2012). Our data also show that the mean informal interest rate was 72 percent as opposed to the 15 percent charged by MFIs in 2000. As a result, we might expect that households who continued to borrow from microfinance may be able to invest more efficiently in inputs, labour and technologies (Sinha and Matin, 1998; Zeller et al., 1997). According to Zeller et al. (1997), access to more affordable credit can also reduce a household's cost of 
insurance against adverse shocks, enabling them to invest in riskier, but also more profitable, projects. Khandker et al. (2013) find that microenterprise profit is 115 per-cent higher for households that borrowed from MFIs, compared to those that borrowed from informal lenders. However, given the scope of this paper and our data availability we cannot directly examine whether these potential benefits are indeed present. This is an area that could be fruitfully examined in future research.

\section{REFERENCES}

Alderman, H., Behrman, J., Kohler, H.-P., Maluccio, J., Watkins, S., 2001. Attrition in longitudinal household survey data some tests for three developing-country samples. Demographic Research 5, 80-123.

Aleem, I., 1990. Imperfect information, screening, and the costs of informal lending:a study of a rural credit market in Pakistan. The World Bank Economic Review 4(3), 329-349.

Armendáriz, B., Morduch, J., 2010. The Economics of Microfinance. MIT Press.

Baltagi, B.H., 2005. Econometric Analysis of Panel Data, vol. 13. Wiley.

Banerjee, A., Duflo, E., Glennerster, R., \& Kinnan, C., 2013. The Miracle of Microfinance?: Evidence from a Randomized Evaluation. CEPR Discussion Paper.

Barham, B.L., Boucher, S., Carter, M.R., 1996. Credit constraints, credit unions, and small-scale producers in Guatemala. World Development 24 (5), 793-806.

Behr, P., Entzian, A., Guttler, A., 2011. How do lending relationships affect access to credit and loan conditions in microlending? Journal of Banking and Finance 35, 2169-2178.

Bellucci, A., Borisov, A., Zazzaro, A., 2010. Does gender matter in bank-firm relationships? Evidence from small business lending. Journal of Banking and Finance 34, 2968-2984.

Berg, C., Emran, M. S., \& Shilpi, F., 2013. Microfinance and Moneylenders: Long-run Effects of MFIs on Informal Credit Market in Bangladesh. World Bank Policy Research Working Paper, September.

Besley, T., Burchardi, K., Ghatak, M., 2012. Incentives and the De Soto effect.Quarterly Journal of Economics 127, 237-282.

Bose, P., 1998. Formal-informal sector interaction in rural credit markets. Journal of Development Economics 56, 265-280. 
Boucher, S., Guirkinger, C., 2007. Risk, wealth, and sectoral choice in rural credit markets. American Journal of Agricultural Economics 89 (4), 991-1004.

Collins, D., Morduch, J., Rutherford, S., Ruthven, O., 2009. Portfolios of the Poor: How the World's Poor Live on $\$ 2$ a Day. Princeton University Press.

Crépon, B., Devoto, F., Duflo, E., \& Pariente, W., 2014. Estimating the Impact of Microfinance on Those Who Take it up: Evidence from a Randomized Experiment in Morocco, Working Paper.

Demont, T. (2010). The Impact of Microfinance on the Informal Credit Market: An Adverse Selection Model, CRED Working Paper.

Falaris, E.M., 2003. The effect of survey attrition in longitudinal surveys: evidence from Peru, Côte d'Ivoire and Vietnam. Journal of Development Economics 70 (1), 133-157.

Fitzgerald, J., Gottschalk, P., Moffitt, R., 1998. An analysis of sample attrition in panel data: the Michigan panel study of income dynamics. The Journal of Human Resources 33 (2), 251-299.

Galema, R., Lensink, R., Mersland, R., 2012. Do powerful CEOs determine microfinance performance? Journal of Management Studies 49 (4), 718-742.

Gertler, P., Levine, D.I., Moretti, E., 2009. Do microfinance programs help families insure against illness? Health Economics 18, 257-273.

Goetz, A.M., Gupta, R.S., 1996. Who takes the credit? Gender, power, and control over loan use in rural credit programs in Bangladesh. World Development 24(1), 45-63.

Greene, W., 2004a. The behaviour of the maximum likelihood estimator of limited dependent variable models in the presence of fixed effects. The Econometrics Journal 7 (1), 98-119. 